\title{
Effect of Betel Leaf (Piper sp.) Water Extracts to Control Penicillium digitatum Causes of Green Mold in Dekopon Citrus (Citrus reticulata)
}

\author{
Ceppy Nasahi*, dan Ria Aghaselly Clonelin \\ Department of Plant Pests and Diseases, Agriculture Faculty, Universitas Padjadjaran, Jatinangor, West Java 45363 \\ *Corresponding Author : c.nasahi@unpad.ac.id
}

Received June 10, 2021; revised June 21, 2021; accepted June 30, 2021

\begin{abstract}
Green mold disease (Penicillium digitatum Sacc.) is one of the main problems in citrus fruits. Some studies had made use of biopesticides in treating postharvest diseases. Some studies reported that plant extracts can suppress various pathogens caused to have antifungal characteristics. One of the plants that are widely used as an extract is green betel leaf (Piper betle) and red betel (Piper ornatum).. This study aims to determine the effect of water extracts from green betel leaf and red betel leaf in suppressing $P$. digitatum in dekopon citrus (Citrus reticulata Shiranui). The experiment used the experimental method of Completely Randomized Design with 7 treatments and 3 replications. The results showed that the water extracts of green betel leaf and red betel can inhibit the pathogen $P$. digitatum both in vitro and in vivo. The red betel leaf water extract at concentration of $10 \%$ was able to inhibit the colony diameter of $P$. digitatum in vitro at $43.61 \%$ and green betel lef extract at concentration of $10 \%$ was $39.34 \%$. The best inhibition of green water extract and red betel the diameter of green mold disease on dekopon fruit was $15.95 \%$ and $39.74 \%$, respectively. The water extracts of green betel leaf and the red betel leaf were able to inhibit green mold disease in vivo successively was $0.52-19.62 \%$ and $17.64-52.67 \%$. The treatment of $10 \%$ green betel water extract was able to suppress the growth of green mold disease in dekopon fruit was $19.62 \%$ and $10 \%$ red betel water extract inhibition was $19.62 \%$.
\end{abstract}

Keywords: dekopon fruit, green betel, green mold disease, red betel, water extract

ABSTRAK

Pengaruh Ekstrak Air Sirih (Piper sp.) Menekan Pertumbuhan Penicillium digitatum, Penyebab Penyakit Green Mold pada Jeruk Dekopon (Citrus reticulata)

Penyakit green mold (Penicillium digitatum Sacc.) merupakan salah satu masalah utama pada buah jeruk di tempat penyimpanan. Kekhawatiran mengenai keselamatan konsumen menyebabkan perlukannya alternatif pengendalian lain untuk menangani penyakit pascapanen. Beberapa penelitian melaporkan penggunaan ekstrak tanaman untuk mengendalikan berbagai patogen karena memiliki sifat antifungi, di antaranya adalah sirih hijau (Piper betle) dan sirih merah (Piper ornatum). Penelitian ini bertujuan untuk mengetahui pengaruh ekstrak air daun sirih hijau dan sirih merah dalam menekan pertumbuhan $P$. digitatum pada jeruk dekopon (Citrus reticulata Shiranui). Percobaan dilakukan dengan menggunakan metode eksperimen Rancangan Acak Lengkap dengan 7 perlakuan dan 4 ulangan. Hasil percobaan menunjukkan ekstrak air daun sirih hijau dan sirih merah dapat menghambat patogen $P$. digitatum secara in vitro dan in vivo. Ekstrak air daun sirih merah konsentrasi 10\% mampu menghambat diameter koloni $P$. digitatum secara in vitro sebesar 43,61\%, sementara ekstrak air daun sirih hijau pada konsentrasi yang sama hanya menghambat pertumbuhan $P$. digitatum sebesar $39,34 \%$. Penghambatan terbaik ekstrak air hijau dan sirih merah konsentrasi $10 \%$ terhadap diameter gejala green mold pada buah dekopon berturut-turut sebesar 15,95\% dan 39,74\%. Ekstrak air daun sirih hijau dan sirih merah mampu menghambat penyakit green mold secara in vivo pada kisaran masing-masing sebesar 0,52-19,62\% dan 17,64-52.67\%. Perlakuan ekstrak air sirih hijau 10\% mampu menekan pertumbuhan penyakit green mold pada buah dekopon sebesar 19,62\% dan ekstrak sirih merah konsentrasi $10 \%$ sebesar $52,67 \%$.

Kata Kunci: buah dekopon, ekstrak air, penyakit green mold, sirih merah, sirih hijau

\section{PENDAHULUAN}

Salah satu pengendalian penyakit yang sedang ramai dikembangkan adalah penggunaan fungisida nabati karena dianggap merupakan salah satu teknik pengendalian yang aman untuk manusia dan lingkungan. Fungisida nabati yaitu bahan yang berasal dari tumbuhan atau bagian tumbuhan daun dan buah yang mampu menghambat perkembangan jamur (Thamrin \& Asikin, 2010). Fungisida nabati banyak digunakan karena ketersediaan bahan baku yang melimpah di alam, proses pembuatannya tergolong mudah karena tidak harus menggunakan teknologi tinggi, mudah terurai sehingga relatif aman bagi lingkungan. Menurut Asmaliyah dkk. (2010), fungisida nabati merupakan jenis pestisida yang dibuat menggunakan metode ekstraksi dengan pelarut tertentu untuk mendapatkan metabolit sekunder yang dihasilkan oleh tanaman sebagai mekanisme pertahanan dari serangan patogen.

Menurut Suri (2015), salah satu tumbuhan yang dapat berpotensi sebagai fungisida nabati adalah daun sirih (Piper sp.). Tanaman sirih tumbuh subur di 
beberapa daerah di Indonesia dan sering dimanfaatkan sebagai pengobatan karena memiliki manfaat sebagai antibakteri, antifungi, dan bahan antiseptik. Sirih di Indonesia terdapat beberapa jenis yang dibedakan berdasarkan bentuk daun, warna, rasa, dan aromanya, yaitu sirih hijau, sirih merah, sirih hitam, sirih cengkih, dan sirih banda (Rizkita dkk. 2017). Menurut Nalina \& Rahim (2007), ekstrak daun sirih berfungsi sebagai antifungi yang dapat menghambat pertumbuhan dan pembentukan konidia fungi. Lebih lanjut Trisnawati \& Efi (2019) juga menyatakan bahwa ekstrak daun sirih hijau konsentrasi $10 \%$ efektif dalam menghambat pertumbuhan Collectotrichum acutatum secara in-vitro dan menghambat penyakit antraknosa pada cabai. Dilaporkan pula oleh Zahara dkk. (2020) pemberian ekstrak daun sirih hijau, dan sirih merah mampu menurunkan persentase infeksi serangan jamur Aspergillus sp.

Tingginya serangan patogen pascapanen menyebabkan mutu produk hortikultura dalam negeri jauh lebih rendah dibandingkan luar negeri. Kehilangan hasil dan kerusakan pascapanen di berbagai negara maju pada buah dan sayuran cukup tinggi sekitar 20-40\% (Hayati dkk., 2015). Pembusukan buah dan sayuran yang dipanen di negara maju akibat penanganan pascapanen yang kurang tepat diperkirakan mencapai 20-25\% (Widiastuti dkk., 2013).

Serangan jamur pada komoditi hortikultura dapat menyebabkan kerugian dan penurunan kualitas hortikultura. Penicillium digitatum merupakan salah satu patogen utama pada buah jeruk yang menyebabkan penyakit kapang hijau (green mold) (Deciana dkk., 2014). Secara umum tingkat busuk buah jeruk yang disebabkan oleh Penicillium sp. sekitar 10-30\%, namun pada kondisi parah dapat meningkat hingga $50 \%$ sehingga mampu menyebabkan kerugian ekonomi yang besar (Chen et al., 2019).

Salah satu produk hortikultura sering mengalami penuruan kualitas karena serangan patogen namun masih digemari dan banyak dikonsumsi masyarakat adalah jeruk. Konsumsi jeruk tahun 1995 sebesar 0,57 kg/kapita/tahun dan tahun 2015 menjadi 3,28 kg/kapita/tahun (BPS, 2016). Produksi buah jeruk keprok (Citrus reticulata) tahun 2018 di Indonesia sebanyak 2.408.043 ton (BPS, 2018). Produksi jeruk meningkat dikarenakan meningkatnya juga jenis jeruk yang di budidayakan di Indonesia.

Jeruk Dekopon (Citrus reticulata Shiranui) menjadi salah satu produk hortikultura yang sedang dikembangkan di Kabupaten Bandung. Jeruk dekopon diharapkan menjadi primadona baru bagi dunia pertanian Indonesia (Balitjestro, 2016). Jeruk Dekopon merupakan salah satu kultivar jeruk keprok hasil persilangan antara Citrus reticulata Bla. dengan Kiyomi tangor (Citrus unshiu Marc. x Citrus sinensis
Osb.) yang buahnya empuk, berair dan sangat manis (Reis et al., 2018).

Menurut Chen et al. (2019), buah jeruk rentan terhadap kerusakan mekanik selama pemanenan, pengemasan, penyimpanan, transportasi dan umur simpan. Oleh sebab itu perlu dilakukan penanganan pascapanen pada buah jeruk utntuk mempertahankan mutu buah. Penanganan pascapanen bisa dilakukan dengan pengaplikasian fungisida nabati seperti ekstrak daun sirih. Namun belum diketahui apakah ekstrak air daun sirih mampu mengendalikan penyakit busuk kapang hijau pada buah jeruk dekopon. Oleh sebab itu perlu dilakukan pengujian ekstrak air daun sirih dalam menekan $P$. digitatum sebagai penanganan pascapanen pada jeruk dekopon.

\section{BAHAN DAN METODE}

\section{Isolasi dan Perbanyakan Biakan $P$. digitatum}

Patogen $P$. digitatum diisolasi dari buah jeruk yang menunjukkan gejala busuk kapang hijau. Isolat yang diperoleh diuji patogenisitasnya dengan menginokulasikan isolat $P$. digitatum diinokulasikan pada buah jeruk dekopon sehat yang sudah disinfeksi permukaannya dengan diusap menggunakan etanol $70 \%$. Pada buah jeruk dibuat luka di dua sisi buah kemudian diletakkan dalam kotak plastik berukuran $30 \times 30 \times 20 \mathrm{~cm}^{2}$. Reisolasi patogen dilakukan terhadap buah jeruk yang menunjukkan gejala terinfeksi P.digitatum yaitu tumbuhnya miselium putih kemudian menjadi spora berwarna hijau. Hasil dari isolasi ini diidentifikasi secara makroskopis dan mikroskopis untuk memastikan isolat yang didapat merupakan jamur P. digitatum.

\section{Pembuatan Suspensi Patogen}

Pembuatan suspensi patogen dengan memanen spora $P$. digitatum dari biakan berumur 6 hari dan disuspensi dalam $10 \mathrm{ml}$ aquades steril dengan menambahkan Tween 80 (Istifadah dkk., 2020). Kemudian suspensi dimasukkan ke tabung reaksi dan di vortex selama 1 menit untuk melepaskan konidia. Kerapatan konidia jamur hasil suspensi dihitung dengan menggunakan haemocytometer hingga diperoleh kerapatan $1 \times 10^{6}$ spora per $\mathrm{ml}(\mathrm{Fu}$ et al., 2014).

\section{Pembuatan Ekstrak Air Daun Sirih}

Daun sirih hijau diperoleh dari Desa Sukasari, Kecamatan Sukasari, Kabupaten Sumedang dan daun sirih merah diperoleh dari Desa Namo Rambe, Kecamatan Namorambe, Kabupaten Deli Serdang, Sumatera Utara. Daun sirih hijau dan sirih merah dicuci secara terpisah dengan air yang mengalir hingga bersih untuk menghilangkan debu dan kotoran pada permukaan daun, kemudian daun tersebut dikeringkan di suhu ruang. Daun tersebut diblender hingga terbentuk serbuk kemudian dipanaskan dalam oven selama 90 menit dengan suhu $60^{\circ} \mathrm{C}$. 
Ekstrak air daun sirih didapatkan dengan metode perendaman selama 24 jam untuk digunakan dalam pengujian in-vitro dan in-vivo. Pengujian in vitro dilakukan dengan merendam serbuk daun dalam aquades steril dengan perbandingan 1:4 dan untuk pengujian in vivo dilakukan dengan merendam serbuk daun dan aquades steril sesuai perlakuan kemudian campuran tersebut diaduk dan disimpan dalam suhu ruang (Birhanu et al., 2013). Setelah itu, hasil rendaman tersebut disaring dengan kain steril dan dimasukkan dalam tabung dan tabung disimpan pada suhu ruangan (Zahara dkk. 2020).

Ekstrak daun sirih hijau dan sirih merah yang digunakan untuk pengujian in-vitro disaring menggunakan kain kasa steril, lalu sentrifugasi selama 15 menit, kemudian disaring menggunakan kertas saring Whatman dan disentrifugasi kembali selama 15 menit. Hasil ekstrak konsentrasi $25 \%$ tersebut di campur ke dalam Ptelah DA yang ditambahkan chloramphenicol $2 \%$ dengan menyesusaikan konsentrasi campuran PDA-ekstrak hingga sesuai perlakuan.

\section{Persiapan Buah Jeruk Dekopon}

Buah diperoleh dari Kebun Mupu Lembang, Jawa Barat. Buah jeruk dekopon yang dipilih yaitu buah sehat yang diambil setelah dipanen dengan ukuran, tingkat kematangan seragam dan berwarna kuning-jingga tanpa menunjukkan gejala serangan patogen untuk meminimalkan gangguan dari infeksi alami. Selanjutnya buah dibawa ke labotarium untuk persiapan perlakuan. Sebelum dilakukan inokulasi, buah jeruk dicelupkan ke dalam aquades steril, alkohol $70 \%$, dan dibilas kembali dengan aquades steril sebanyak dua kali dan dikeringanginkan.

\section{Uji Aktivitas Antifungi Ekstrak Air Daun Sirih secara In-Vitro}

Pengujian dilakukan menggunakan metode umpan beracun (poisoned food technique) seperti yang dilakukan oleh Bena dkk. (2017). Pengujian dilakukan dengan memasukkan media PDA yang sudah tercampur ekstrak air daun sirih sesuai dengan perlakuan ke dalam cawan petri dan untuk perlakuan kontrol hanya menggunakan PDA. Inokulasi $P$. digitatum dilakukan dengan cara meletakkan inokulum berumur 7 hari diameter $5 \mathrm{~mm}$ pada bagian tengah cawan, kemudian diinkubasi dan diamati setiap hari selama 7 hari.

\section{Uji Aktivitas Esktark Air Daun Sirih secara In- Vivo pada Buah Jeruk}

Inokulasi patogen pada buah jeruk dilakukan dengan cara memberi dua luka di dua sisi kulit jeruk dengan menggunakan jarum berukuran $2 \mathrm{~mm}$ dan kedalaman $1 \mathrm{~mm}$ (Musto et al., 2014). Pada setiap lubang diteteskan sebanyak $5 \mu$ (kerapatan $1 \times 10^{6}$ spora/ml) suspensi spora $P$. digitatum. Setelah kering angin, selanjutnya bagian yang diinokulasi ditutup menggunakan kapas yang telah dilembabkan. Buah jeruk didiamkan selama 3 jam sebelum aplikasi esktrak air daun sirih hijau dan daun sirih merah (Inkha \& Booyakiat, 2010).

Buah jeruk dekopon direndam ke dalam larutan ekstrak air daun sirih sesuai dengan jenis dan konsentrasi masing-masing perlakuan selama 10 menit (Musto et al., 2014). Luka pada buah ditutup kembali dengan kapas lembab dan ditutup dengan plastik wrap kemudian diinkubasikan dalam kotak tertutup yang telah disinfeksi dengan alkohol $70 \%$. Untuk perlakuan kontrol, buah jeruk direndam dalam air sebagai pengganti larutan ekstrak. Setiap wadah plastik berisi 2 buah jeruk dekopon yang disusun secara terpisah kemudian diletakkan di atas meja pada kondisi suhu ruang. Plastik wrap dibuka 3 hari atau buah sudah menunjukkan gejala setelah inokulasi.

\section{Pengamatan \\ Pengujian secara In-Vitro}

Variabel yang diamati pada pengujian in-vitro adalah diameter koloni patogen dan daya hambat ekstrak air daun sirih hijau dan daun sirih merah terhadap pertumbuhan koloni patogen. Pengamatan dilakukan setiap hari sampai 7 hari setelah inokulasi. Besarnya persentase penghambatan dihitung dengan rumus sebagai berikut:

$$
\text { DH : : } \frac{K-P}{K} \times 100 \%
$$

Keterangan :

DH : Persentase penghambatan

$\mathrm{K}$ : diameter koloni jamur patogen kontrol $(\mathrm{cm})$

$\mathrm{P}$ : diameter koloni jamur patogen yang diberi perlakuan $(\mathrm{cm})$

\section{Pengujian secara In-Vivo}

Pengamatan dilakukan setiap hari sampai seluruh permukaan pada kontrol bergejala (Fieira et al., 2015). Parameter yang diamati adalah masa inkubasi (hari), diameter koloni jamur $P$. digitatum $(\mathrm{cm})$, dan luas serangan. Pengamatan masa inkubasi dilaksanakan bersamaan dengan diameter koloni pada hari ke 3 atau setelah jeruk mulai menunjukkan gejala kapang hijau. Diameter koloni diukur dari diameter terpanjang dengan menggunakan tali kemudian dihitung diameternya menggunakan mistar. Gejala yang muncul di jeruk digambar di atas plastik mika kemudian luas serangan diukur dengan bantuan kertas millimeter block. Data yang diperoleh digunakan untuk menghitung Area Under Desease Progress Curve (AUDPC):

Rumus AUDPC juga tidak ada, ini saya tambahkan rumusnya.

$$
A U D P C=\sum_{i=1}^{n-1}\left(\frac{X_{i}+X_{i+1}}{2}\right)\left(t_{i+1}-t_{i}\right)
$$

Keterangan :

$\mathrm{Y}_{\mathrm{i}} \quad=$ luas gejala penyakit pada saat $\mathrm{i}$

$\mathrm{Y}_{\mathrm{i}}+1=$ luas gejala penyakit pada saat $\mathrm{i}+1$

$\mathrm{t} \quad=$ beda waktu antar pengamatan

$\mathrm{t}_{\mathrm{i}}+1=$ waktu pengamatan saat $\mathrm{i}+1$ 
Persentase penghambatan pertumbuhan $P$. digitatum dihitung dengan menggunakan rumus :

Penghambatan: $\left[1-\frac{\text { AUDPC Perlakuan }}{\text { AUDPC Kontrol }}\right] \times 100 \%$

\section{HASIL DAN PEMBAHASAN}

Pengaruh Ekstrak Air Daun Sirih Hijau dan Sirih Merah terhadap Pertumbuhan Koloni jamur $\boldsymbol{P}$. digitatum secara in vitro

Hasil pengujian yang dilakukan secara in vitro menunjukkan bahwa ekstrak air daun sirih hijau maupun sirih merah mampu menghambat pertumbuhan $P$. digitatum sebesar 14,35 - 43,61\%. Aplikasi ekstrak daun sirih hijau 5\%, 7,5\%, 10\% dan sirih merah $5 \%$ dan $7,5 \%$ memiliki persentase penghambatan rendah daripada perlakuan daun sirih merah $10 \%$ dengan penghambatan terbaik yaitu $43,61 \%$ terhadap patogen $P$. digitatum. Secara statistik perlakuan sirih merah $10 \%$ memberikan pengaruh lebih baik daripada perlakuan lainnya namun tidak berbeda nyata dengan perlakuan sirih hijau $10 \%$ (Tabel 1).

Tabel 1. Penghambatan pertumbuhan koloni jamur $P$. digitatum pada perlakuan ekstrak air daun sirih hijau dan sirih merah pada berbagai konsentrasi

\begin{tabular}{lcc}
\hline \multicolumn{1}{c}{ Perlakuan } & Rata-Rata Diameter Koloni $(\mathbf{c m})$ & Penghambatan $(\%)$ \\
\hline Kontrol & $3,55 \mathrm{c}$ & 0 \\
Sirih Hijau 5,0\% & $3,06 \mathrm{~b}$ & 14,35 \\
Sirih Hijau 7,5\% & $2,75 \mathrm{~b}$ & 25,08 \\
Sirih Hijau 10,0\% & $2,00 \mathrm{a}$ & 39,34 \\
Sirih Merah 5,0\% & $2,82 \mathrm{~b}$ & 22,94 \\
Sirih Merah 7,5\% & $2,71 \mathrm{~b}$ & 26,07 \\
Sirih Merah 10,0\% & $2,07 \mathrm{a}$ & 43,61 \\
\hline
\end{tabular}

Keterangan : Huruf yang sama pada satu kolom dalam tabel menunjukkan data tidak berbeda nyata berdasarkan Uji Duncan pada taraf $5 \%$

Ekstrak sirih yang diberikan diduga mengganggu metabolisme $P$. digitatum yang berdampak pada pertumbuhan koloni suatu jamur (Zahara dkk. 2020). Hal ini dapat dilihat pada Tabel 1. bahwa pemberian ekstrak sirih dapat memperkecil diameter koloni $P$. digitatum (Gambar 1). Pemberian konsentrasi ekstrak yang meningkat menyebabkan pertumbuhan jamur terhambat. Hal ini disebabkan karena jumlah senyawa antifungi yang terkandung pada ekstrak akan meningkat juga.

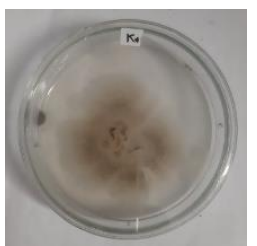

Kontrol

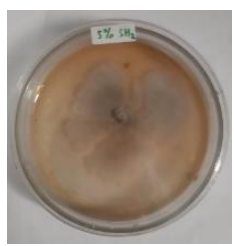

Sirih Hijau $5 \%$

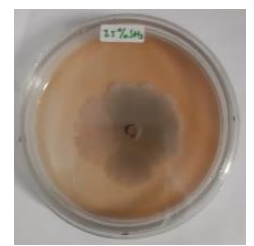

Sirih Hijau 7,5\%

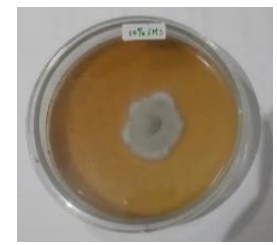

Sirih Hijau $10 \%$

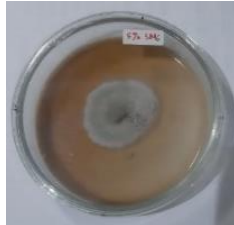

Sirih Merah $5 \%$

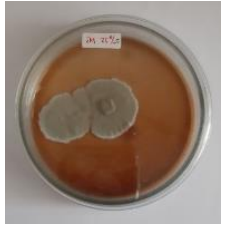

Sirih Merah 7,5\%

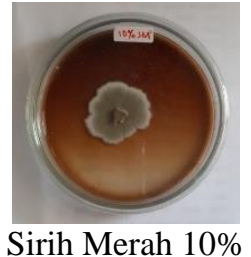

Gambar 1. Pertumbuhan $P$. digitatum pada berbagai konsentrasi ekstrak air daun sirih

Hasil pengujian in vitro menunjukkan bahwa ekstrak sirih merah mampu menghambat $P$. digitatum lebih baik daripada ekstrak sirih hijau. Perbedaan efektifitas antara ekstrak air sirih hijau dan sirih merah diduga karena perbedaan kandungan senyawa kimia. Hal ini didukung oleh Dwianggraini dkk. (2015) yang menyatakan bahwa senyawa antifungi pada daun sirih merah antara lain yaitu flavonoid, alkaloid senyawa polifenolat, tannin dan minyak atsiri. Minyak atsiri merah mengandung kavikol, fenol, eugenol, trans-karyopilen dan betaselinen (Dwianggraini dkk., 2015). Minyak atsiri pada daun sirih terdiri dari betephenol yang merupakan isomer eugenol, allypyrocatechine, cineol methyl eugenol, caryophyllene, kaviol, kavibekol, estragol, dan terpinene. Pada penelitian lain menyatakan bahwa minyak atsiri pada daun sirih hijau terdiri dari alikatekol, kadinen, karvavol, kariofilen, kavibetol, kavikol, sineol, eugenol, eugenol metil eter, dan pirokatekin. Mekanisme kerja senyawa fenol fenol 
dan flavonoid dalam ekstrak daun sirih hijau dan sirih merah kontak dengan sel dan spora jamur yang menyebabkan perubahan struktur protein dinding sel kemudian mengakibatkan struktur protein dinding sel berubah dan terganggunnya mekanisme permeabilitas membran sel sehingga sel mikroba menjadi rusak atau lisis (Saraswati, 2011).

Faktor lain yang mendukung esktrak daun sirih merah memberikan hasil lebih baik daripada ekstrak daun sirih hijau adalah penggunaan bahan ekstrak dari daerah yang berbeda. Penggunaan daun dari daerah yang berbeda dikarenakan sulitnya menemukan daun sirih merah dalam stok yang banyak.. Selain sulit untuk ditemukan, harga daun sirih merah yang tergolong mahal menjadi kendala peneliti. Tanaman sirih merah memiliki nilai jual yang tinggi karena penampilannya yang indah dan khasiatnya yang dinilai mampu menyembuhkan berbagai jenis penyakit (Rahmawati \& Kurniawati, 2016).

Pada pengujian perlakuan ekstrak sirih merah (asal Sumatera Utara) mampu menghambat sebesar 22,94 - 43,61\% sedangkan perlakuan ekstrak sirih hijau (asal Jawa Barat) menghambat sebesar 14,35 $39,34 \%$. Penggunaan bahan dari daerah yang berbeda akan mempengaruhi komponen kimia daun sirih. Kompenen kimia dari metabolit sekunder daun sirih dipengaruhi oleh faktor ekologi seperti tempat tumbuh, iklim, dan jenis tanah. Kemampuan minyak atsiri dan senyawa lainnya sebagai antifungi sangat dipengaruhi oleh komponen kimia penyusunnya (Ridawati dkk., 2011). Hasil skrining fitokimia senyawa aktif ekstrak daun sirih hijau asal Boyolali, Jawa Tengah terdiri dari flavonoid, saponin, tanin, terpenoid, dan fenol dan ekstrak sirih merah asal Medan Johor, Sumatera Utara terdiri dari alkaloid, flavoid, steroid, tanin dan fenol (Siregar dkk. 2015, Pangesti dkk. 2017). Hal tersebut sesuai dengan Sripadha (2014) bahwa kandungan dan kemampuan senyawa aktif dalam daun sirih tergantung pada varietas, musim, dan cuaca di daerah tumbuhnya. Perbedaan kandungan senyawa kimia akibat beda lingkungan hidup diduga mempengaruhi nilai toksisitas ekstrak terhadap patogen $P$. digitatum.

\section{Pengaruh Ekstrak Air Daun Sirih Hijau dan Sirih Merah terhadap $\boldsymbol{P}$. digitatum pada Buah Jeruk Dekopon \\ Pengaruh Ekstrak Air Daun Sirih Hijau dan Sirih Merah terhadap Diameter Gejala Green Mold pada Buah Jeruk Dekopon}

Hasil Pengujian ekstrak air daun sirih hijau dan sirih merah pada berbagai konsentrasi memiliki penghambatan yang berbeda-beda dalam menekan green mold pada jeruk dekopon (Tabel 2). Selain perlakuan kontrol negatif, perlakuan sirih merah $10 \%$ memberikan pengaruh lebih baik dan berbeda nyata dengan perlakuan lainnya. Persentase penghambatan tertinggi yaitu pada perlakuan sirih merah konsentrasi $10 \%$ sebesar 39,74\%, meskipun persentase penghambatan rendah, secara statistik berbeda nyata dengan kontrol. Pada percobaan ini, perlakuan dengan ekstrak sirih merah $10 \%$ menunjukkan efek penghambatan yang relatif lebih tinggi dibandingkan dengan perlakuan lainnya. Hal ini sesuai dengan hasil percobaan in vitro dimana ekstrak sirih merah $10 \%$ memang menunjukkan efek penghambatan tertinggi terhadap pertumbuhan patogen.

Tabel 2. Penghambatan pertumbuhan diameter gejala green mold dekopon pada perlakuan ekstrak air daun sirih hijau dan sirih merah berbagai konsentrasi

\begin{tabular}{lll}
\hline Perlakuan & Rata-Rata Diameter Koloni (cm) & Penghambatan $(\boldsymbol{\%})$ \\
\hline Sirih Hijau 5,0\% & $2,70 \mathrm{~cd}$ & 4,66 \\
Sirih Hijau 7,5\% & $2,66 \mathrm{~cd}$ & 7,35 \\
Sirih Hijau 10,0\% & $2,52 \mathrm{bc}$ & 17,08 \\
Sirih Merah 5,0\% & $2,53 \mathrm{bc}$ & 15,95 \\
Sirih Merah 7,5\% & $2,38 \mathrm{~b}$ & 25,76 \\
Sirih Merah 10,0\% & $2,13 \mathrm{a}$ & 39,74 \\
Kontrol Positif (diinokulasi) & $2,77 \mathrm{~d}$ & 0 \\
Kontrol Negatif (tidak diinokulasi) & 0 & 100 \\
\hline
\end{tabular}

Keterangan : Huruf yang sama pada satu kolom dalam tabel menunjukkan data tidak berbeda nyata berdasarkan Uji Duncan pada taraf 5\%

Penghambatan semakin tinggi ditunjukkan dengan penambahan konsentrasi ekstrak sirih yang semakin tinggi. Hal ini sesuai dengan Ariyanti dkk. (2012), semakin tinggi konsentrasi ekstrak air daun sirih hijau dan sirih merah dapat meningkatkan persentase penghambatan pertumbuhan koloni jamur. Penghambatan ekstrak air daun sirih hijau dan sirih merah terhadap pertumbuhan koloni jamur patogen uji, diperkirakan karena adanya senyawa antifungi yang terkandung dalam daun sirih. Daun sirih memiliki sifat antifungi dengan komponen minyak atsiri yaitu eugenol, acetyluegenol dan fenol yang mampu menghambat pertumbuhan patogen (Prakash et al., 2010).

Hasil pengamatan menunjukkan bahwa pada percobaan ini belum menunjukkan sifat fungisidal karena masih memberi kesempatan sel jamur untuk tumbuh atau bereproduksi. Senyawa ekstrak sirih 
hijau dan sirih merah diduga bersifat fungistatik yang dapat menghambat pertumbuhan jamur tanpa mematikannya (Setiari dkk., 2019). Sifat fungistastik ini diduga yang menyebabkan aplikasi ekstrak daun sirih hijau dan sirih merah tidak berpengaruh nyata terhadap masa inkubasi dan waktu penyimpanan.

Ekstrak daun sirih mengandung fenil propane (senyawa fenolik) yang bersifat fungistatik (Damayanti \& Mulyono, 2008). Minyak atsiri daun sirih mengandung $60-80 \%$ fenil propane. Mekanisme senyawa tersebut adalah denaturasi protein yaitu kerusakan struktur tersier protein menyebabkan hilangnya protein dan mengganggu metabolisme jamur sehingga proses reproduksi terhambat (Rahmah \& Aditya, 2018)

Perbedaan kemampuan daya hambat pada pengujian ini diduga karena terdapat perbedaan kandungan antara ekstrak daun sirih merah dan sirih hijau. Faktor lain yang mempengaruhi daya hambat ekstrak sirih merah lebih besar daripada sirih hijau karena penggunaan sumber daun dari daerah yang berbeda. Sulitnya mendapat stok daun sirih merah dari daerah yang sama dengan sirih hijau atau dari daerah di Pulau Jawa mengakibatkan peneliti menggunakan sirih merah dari daerah sumatera utara. Hal ini didukung oleh jumlah daun sirih di Pulau Sumatera lebih banyak daripada Pulau Jawa (Munawaroh \& Yuzammi, 2017). Ekstrak sirih merah diduga lebih baik karena adanya perbedaan asal sumber bahan ekstrak yang mempengaruhi komposisi senyawa

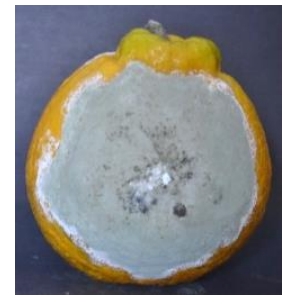

Sirih Hijau 5\%

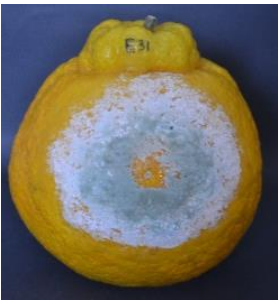

Sirih Merah 7,5\%
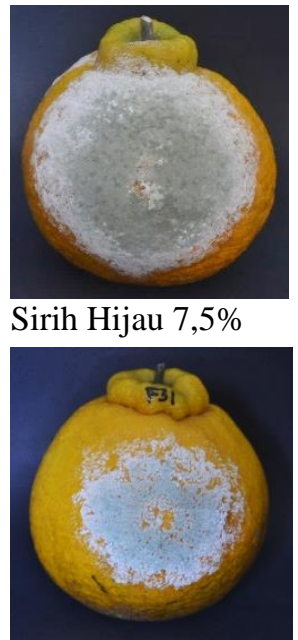

Sirih Merah 10\%

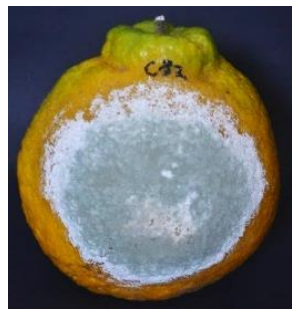

Sirih Hijau $10 \%$

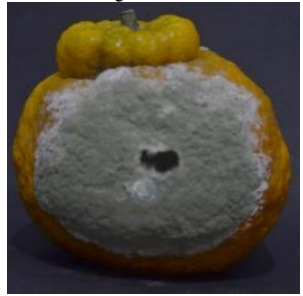

Kontrol Positif

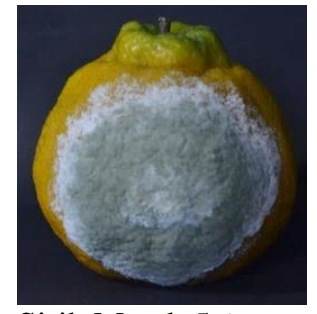

Sirih Merah 5\%

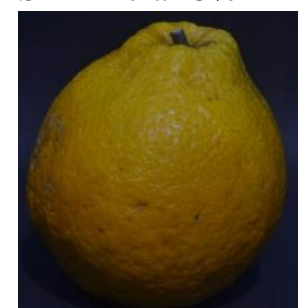

Kontrol Negatif

Gambar 2. Pengaruh aplikasi ekstrak air daun sirih hijau dan sirih merah berbagai konsentrasi pada jeruk dekopon

Peningkatan kerusakan yang signifikan terlihat pada kontrol dari hari ke-3 hingga ke 8 setelah inokulasi (Gambar 3). Pengamatan pada percobaan ini berakhir pada hari ke-8 setelah inokulasi karena kondisi buah perlakuan kontrol sudah rusak lebih dari $50 \%$. Hal ini menunjukkan bahwa aplikasi ekstrak daun sirih hijau dan sirih merah tidak berpengaruh terhadap waktu penyimpanan. Hal tersebut diduga karena perkembangan patogen yang tergolong cepat.
Jamur biasanya menyebar dengan cepat dan dapat membusukkan seluruh jaringan buah (Istifadah dkk. 2017). Penyusutan kuantitatif yaitu kehilangan jumlah atau bobot buah karena adanya gangguan biologi atau penanganan pascapanen yang kurang tepat (Muchtar \& Kamsina 2011). Buah jeruk dekopon mengalami penyusutan bobot (data tidak ditampilkan) diduga karena adanya pertumbuhan mikroorganisme. 
Aplikasi ekstrak air daun sirih hijau dan sirih merah dapat menghambat perkembangan gejala kapang hijau pada jeruk dekopon. Perkembangan gejala perlakuan sirih merah lebih lambat daripada perlakuan sirih hijau (Gambar 3).

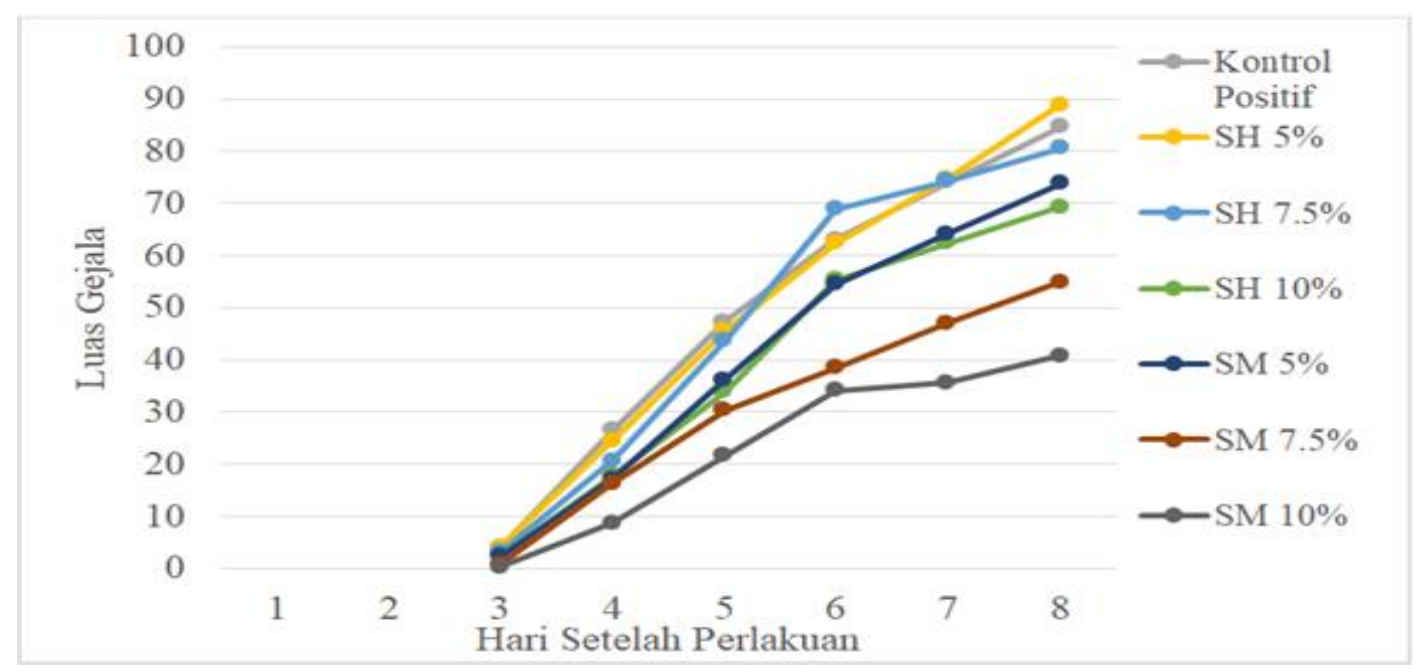

Gambar 3. Perkembangan penyakit green mold setelah perlakuan

Total perkembangan penyakit kapang hijau selama pengamatan dapat diketahui dengan menghitung nilai daerah di bawah kurva perkembangan penyakit atau Area Under Disease Progress Curve (AUDPC). Semakin kecil nilai AUDPC maka semakin besar persentase penghambatan yang diberikan (Gunaeni dkk. 2015).
Hal ini terlihat pada Tabel 3. bahwa semakin kecil nilai AUDPC maka semakin besar persentase penghambatannya. Pada percobaan ini aplikasi ekstrak air daun sirih hijau maupun sirih merah dapat menekan penyakit kapang hijau sebesar 0,52\%$52,67 \%$ (Tabel 3).

Tabel 3. Total perkembangan penyakit green mold pada buah jeruk dekopon di berbagai perlakuan

\begin{tabular}{lll}
\hline Perlakuan & Nilai AUDPC & Penghambatan (\%) \\
Sirih Hijau 5,0\% & $253,74 \mathrm{c}$ & 0,52 \\
Sirih Hijau 7,5\% & $249,28 \mathrm{c}$ & 2,27 \\
Sirih Hijau $10,0 \%$ & $205,03 \mathrm{bc}$ & 19,62 \\
Sirih Merah $5,0 \%$ & $210,07 \mathrm{bc}$ & 17,64 \\
Sirih Merah 7,5\% & $160,06 \mathrm{ab}$ & 37,26 \\
Sirih Merah $10,0 \%$ & $120,74 \mathrm{a}$ & 52,67 \\
Kontrol Positif (diinokulasi) & $255,07 \mathrm{c}$ & 0 \\
Kontrol Negatif (tidak diinokulasi) & 0 & 100 \\
\hline
\end{tabular}

Keterangan : Huruf yang sama pada satu kolom dalam tabel menunjukkan data tidak berbeda nyata berdasarkan Uji Duncan pada taraf 5\%

Perlakuan sirih merah $10 \%$ memberikan pengaruh lebih baik dan secara statistik tidak berbeda nyata dengan perlakuan sirih merah 7,5\%. Aplikasi ekstrak air daun sirih merah konsentrasi $10 \%$ menunjukkan efek penekanan terbaik yaitu $52,67 \%$ dibandingkan dengan kontrol. Sedangkan perlakuan sirih hijau konsentrasi 5\%, 7,5\% dan $10 \%$ tidak berbeda nyata dengan perlakuan kontrol.

Kemampuan daya hambat ekstrak daun sirih merah menghambat $P$. digitatum lebih besar kemungkinan karena senyawa yang terkandung pada daun sirih merah lebih kuat. Daya antifungi ini mungkin terbentuk disebabkan oleh adanya alkaloid. Sudewo (2010) menyatakan bahwa perbedaan kandungan senyawa daun sirih merah dengan sirih hijau yaitu daun sirih merah mengandung alkaloid. Alkaloid berikatan kuat dengan ergosterol menyebabkan membran sel bocor yang mengakibatkan kerusakan yang tetap pada sel (Anggraini \& Masfufatun, 2017). Mekanisme aktivitas antifungi senyawa fitokimia yaitu penghambatan sintesis dinding sel, distrupsi membran sel dan terjadinya gangguan metabolism sel (Bena dkk. 2017).

Kemampuan daya hambat ekstrak daun sirih merah lebih besar daripada sirih hijau juga diduga karena penggunaan bahan ekstrak dari daerah yang berbeda. Kandungan minyak atsiri dan senyawa 
lainnya dipengaruhi beberapa hal antara lain tempat tumbuh, suhu, komposisi mineral, kandungan air, dan kelembaban (Koensoemardiyah, 2010). Perbedaan kandungan senyawa ekstrak sirih hijau dan sirih merah dari lingkungan yang berbeda mempengaruhi nilai toksisitas terhadap patogen $P$. digitatum.

Hasil pengamatan menunjukkan perlakuan kontrol negatif berbeda nyata dengan kontrol positif. Kontrol negatif tidak menunjukkan gejala kapang hijau hingga waktu penyimpanan perlakuan lainnya tercapai sehingga data pengamatan tidak dimasukkan ke dalam perhitungan statistik. Kontrol negatif tidak menunjukkan gejala diduga karena tidak patogen $P$. digitatum tidak diinokulasikan pada buah. Faktor lain yang mempengaruhi jeruk tidak terserang patogen karena memiliki ketahanan buah dekopon yang baik dan memiliki fisik yang lebih baik dari varietas jeruk lainnya karena kulitnya yang tebal. Hal ini bisa menjadi faktor sulitnya jamur menyerang jeruk meskipun kondisi yang mendukung.

Penggunaan ekstrak daun sirih pada berbagai konsentrasi mampu menghambat pertumbuhan $P$. digitatum dan gejala kapang hijau pada buah jeruk dekopon. Meskipun tergolong menunjukkan hasil yang positif, perlu dilakukan pengujian selanjutnya agar tercapai aktivitas pengendalian yang maksimal.

\section{KESIMPULAN DAN SARAN}

Berdasarkan hasil yang diperoleh, maka dapat diambil simpulan :

1. Ekstrak air daun sirih hijau dan sirih merah mampu dalam menekan $P$. digitatum penyebab green mold pada jeruk dekopon (C. reticulata Shiranui).

2. Konsentrasi ekstrak terbaik dalam menekan pertumbuhan penyakit busuk kapang hijau pada buah jeruk dekopon yaitu perlakuan ekstrak air daun sirih merah pada konsentrasi $10 \%$ dengan penghambatan sebesar $52,67 \%$.

\section{DAFTAR PUSTAKA}

Alilou H, Akssira M, Hassani LMI, Chebli B, ElHakmoui A, Mellouki F, \& Blázquez MA. 2008. Chemical composition and antifungal activity of Bubonium imbricatum volatile oil. Phytopathologia Mediterranea. 47(1), 3-10.

Anggraini D, Riezki, Astuti P, Peni, Emawati, \& Tantin. 2015. Perbedaan efektivitas antibakteri antara ekstrak daun sirih merah (Piper crocatum) dan ekstrak daun sirih hijau (Piper betle) terhadap Porphyromonas gingivatis. JKG Stomatognatic. 10 (1): 1-5.

Anggraini V, \& Masfufatun M. 2017. Efektivitas kombinasi ekstrak daun sirih merah (Piper crocatum) dan ekstrak biji alpukat (Persea americana) dalam menghambat pertumbuhan Candida albicans. Jurnal Kimia Riset, 2(2), 86-92.

Ariyanti E, Jahuddin R, \& Yunus M. 2012. Potensi ekstrak daun sirih (Piper betle Linn) sebagai biofungisida penyakit busuk buah stroberi (Collectotrichum fragarie Brooks) secara invitro. Agroteknos. 2(3) : 150-155.

Asmaliyah, Wati EE, Utami S, Mulyadi K, Yudhistira, \& Sari FW. 2010. Pengenalan Tumbuhan Penghasil Pestisida Nabati dan Pemanfaatannya secara Tradisional. Badan Penelitian dan Pengembangan Kehutanan. Palembang. Hal 58.

Badan Pusat Statistik. 2016. Produksi Jeruk Indonesia.

Badan Pusat Statistik. 2018. Statistik Produksi Hortikultura Tahun 2018.

Balitjestro. 2016. Jeruk Dekopon. Balai Penelitian Tanaman Jeruk dan Buah Subtropika. Jawa Timur.

Bena L, Achmad M, \& Syamsul F. 2017. Aktivitas antifungi ekstrak daun picung terhadap cendawan Botryodiplodia theobromae penyebab mati pucuk bibit jabon merah. Silvikultur Tropika Vol 8(2) : 110-115.

Birhanu S, Akhtar MS, \& Muleta D. 2014. Management of post-harvest fruit spoilage fungi by some potential spice extracts. Archives of Phytopathology and Plant Protection. 47(17), 2124-2140.

Chen J, Shen Y, Chen C, \& Wan C. 2019. Inhibition of key citrus postharvest fungal strains by plant extracts in vitro and in vivo: A review. Plants. 8(2): 1-19.

Damayanti M, \& Mulyono. 2008. Khasiat dan Manfaat Daun Sirih, Obat Mujarab dari Masa ke Masa. PT Agro Media Pustaka: Depok.

Deciana D, Nurdin M, \& Maryono T. 2014. Inventarisasi jamur-jamur patogen pada buah jeruk (Citrus sp.) di beberapa pasar di Bandar Lampung. Agrotek Tropika. 2(2): 193-196.

Fieira C, Oliveira F, Calegari RP, Machado A, \& Coelho AR. 2013. In vitro and in vivo antifungal activity of natural inhibitors against Penicillium expansum. Cienc Tecnol Aliment 33 (1): 40-46.

Fu Liu-Hui, Hu Kang-Di, Hu Lan-Ying, Li YanHong, Hu Ling-Bin, Yan H, Liu Yong-Sheng, \& Zhang H. 2014. An antifungal role on hydrogen sulfide one the postharvest pathogens Aspergillus niger and Penicillium italicum. PLoS ONE. 9 (8): e104206.

Hayati R, Syamsuddin, \& Halimursyadah. 2015. Teknologi Pascapanen. Universitas Syiah Kuala : Banda Aceh.

Inkha S, \& Booyakiat, D. 2010. Induction of resistance to Penicillium digitatum in tangerine fruit cv. Sai Num Phung flavedo by hot water treatment. Songklanakarin J.Sci. and Technol Vol 32 (5) : 445-451.

Istifadah N, Ayuningtyas A, \& Nasahi C. 2017. Efek pencampuran bahan pestisida nabati terhadap keefektifannya dalam menekan Collectotrichum sp. in vitro serta penyakit 
antraknosa pada stroberi. Agrologia. 6 (1): 2636.

Muchtar H, Kamsina, \& Anova IT. 2011. Pengaruh kondisi penyimpanan terhadap pertumbuhan jamur pada gambir. Dinamika Penelitian Industri. 22(1): 36-43.

Munawaroh E, \& Yuzammi. 2017. Keanekaragaman Piper (Piperaceae) dan konservasinya di taman nasional bukit barisan selatan. Media Konservasi. 22(2): 118-128.

Musto M, Potenza G, \& Francesco C. 2014. Inhibition of Penicillium digitatum by a crude extract from Solanum nigrum leaves. Biotechnol. Agron. Soc. Environ. 18(2): 174-180.

Nalina T, \& Rahim ZHA. 2007. The crude aqueous extract of Piper betle $L$. and its antibacterial effect towards Streptococcus mutans. Am J Biotechnol Biochem. 3(1), 10-15.

Rahmah N, \& Aditya R. 2018. Uji fungistatik ekstrak daun sirih (Piper betle L.) terhadap Candida albicans. Bioscientiae. 7(2): 17-24.

Rahmawati A, \& Kurniawati A. 2016. Pertumbuhan beberapa jenis sirih (Piper spp.) pada berbagai intensitas naungan. Bul Agrohorti 4 (3): 288297.

Pangesti DR, \& Cahyono E, \& Kusumo E. 2017. Perbandingan daya antibakteri ekstrak dan minyak Piper betle L. terhadap bakteri Streptococcus mutans. Indonesian Journal of Chemical Science. 6(3): 271- 278.

Prakash B, Shukla R, Singh P, Kumar A, Mishra P K, \& Dubey NK. 2010. Efficacy of chemically characterized Piper betle L. essential oil against fungal and aflatoxin contamination of some edible commodities and its antioxidant activity. International Journal of Food Microbiology, 142(1-2): 114-119.

Ridawati, Jenie BSL., Djuwita I, \& Sjamsuridzal W. 2011. Aktivitas antifungal minyak atsiri jenten putih terhadap Candida parapsilosi ss25, C.orthopilosis nn14, C. metaplosis mp27, dan C. etchellsii mp18. Makara Journal of Sains. 15(1): 58-62.

Reis L, Ferreira E, Elias H, Boas E, \& Rios A. 2018. Postharvest conservation of fresh and minimally processed 'Dekopon' Tangerine in Different Temperatures and Storage Times. Brazilian Journal of Food Research. 9(1) : 112124.
Rizkita A, Cahyono E, \& Mursiti S. 2017. Isolasi dan uji antibakteri minyak daun sirih hijau dan sirih merah terhadap Streptococcus mutans. IJC Science. 6(3):280-286.

Saraswati D. 2011. Pengaruh konsentrasi ekstrak daun sirih terhadap daya hambat Eshrichia coli. Jurnal Health dan Sport. 3(2): 285-362.

Setiari Ni M, Ristiati Ni P, \& Warpala IW. 2019. Aktivitas antifungi kombinasi ekstrak daun sirih (Piper betle) dan ekstrak kulit buah jeruk (Citrus reticulata) untuk menghambat pertumbuhan Candida albicans. JJPB Undiksha. 6(2): 72-82.

Siregar A, Harahap U, \& Mardianto. 2015. Ekstrak etanol daun sirih merah (Piper crocatum) menurunkan kadar gula darah mencit diabetes. Jurnal Ilmiah Manuntung. 1(1): 42-46.

Sripradha S. 2014. Betel leaf - the green gold. J. Pharm. Sci \& rev. 6(1): 36-37.

Sudewo B. 2010. Basmi Penyakit dengan Sirih Merah. Jakarta: Agromedia.

Suri A. 2015. Pengaruh Jenis dan Taraf Konsentrasi Fraksi Ekstrak Air Daun Sirih Hijau (Piper betle) dan Fraksi Ekstrak Metanol daun Babadotan (Ageratum conyzoides) terhadap Pertumbuhan dan Sporulasi Colletotrichum capsici. Seminar Nasional Sains \& Teknologi VI Lembaga Penelitian dan Pengabdian Universitas Lampung. Lampung.

Thamrin M, \& Asikin S. 2010. Potensi Ekstrak Flora Lahan Rawa sebagai Pestisida Nabati. Balai Penelitian Pertanian Lahan Rawa. Banjar Baru. Hal. 35-54.

Trisnawati D, \& Efi T. 2019. Pengaruh ekstrak daun sirih dan metode ekstraksinya dalam menghambat penyakit antraknosa pada cabai pascapanen. Jurnal Fitopatologi Indonesia. 15(6): 213-227.

Widiastuti A, Ningtyas OH, \& Priyatmojo A. 2015. Identifikasi cendawan penyebab penyakit pascapanen pada beberapa buah di Yogyakarta. JurnalFitopatologi Indonesia. 11(3): 91-96.

Zahara N, Ali M, \& Puspita F. 2020. Uji kemampuan ekstrak daun beberapa jenis sirih (Piper sp.) untuk mengendalikan jamur Aspergillus sp. pada benih kacang tanah secara in vitro. Konservasi Hayati. 16 (1): 30-38.

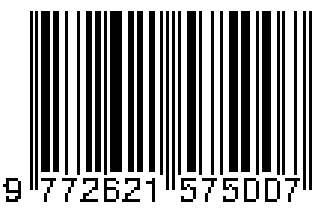

